\title{
Effects of Chemical Ischemia on Purine Nucleotides, Free Radical Generation, Lipids Peroxidation and Intracellular Calcium Levels in $\mathrm{C}_{2} \mathrm{C}_{12}$ Myotube Derived from Mouse Myocytes
}

\author{
Federico Martin BOFFI ${ }^{1}$, Junichiro OZAKI ${ }^{1}$, Naoaki MATSUKI ${ }^{1}$, Mutsumi INABA ${ }^{1)}$, Eduardo DESMARAS ${ }^{2}$ and \\ Kenichiro $\mathrm{ONO}^{1) *}$ \\ ${ }^{1)}$ Department of Veterinary Clinical Pathobiology, Graduate School of Agricultural and Life Sciences, The University of Tokyo, 1-1-1 \\ Yayoi, Bunkyo-Ku, Tokyo 113-8657, Japan and ${ }^{2)}$ Department of Physiology, Faculty of Veterinary Sciences, University of La Plata, CC \\ 296, 60 y 118-20, 1900 La Plata, Bs. As., Argentina
}

(Received 21 August 2001/Accepted 19 February 2002)

\begin{abstract}
To elucidate the mechanisms of ischemia-mediated myopathy using in vitro model, changes of purine nucleotides, membrane lipid peroxidation(TBARS), intracellular calcium ([Ca $\left.{ }^{2+}\right]$ i)levels, generation of free radicals, and deoxyribonucleic acid (DNA) fragmentation were examined in mouse-derived $\mathrm{C}_{2} \mathrm{C}_{12}$ myotubes under the condition with an inhibition of glycolytic and oxidative metabolism as the ischemic condition. In purine nucleotides, intracellular adenosine triphosphate (ATP) and guanosine triphosphate (GTP) concentrations rapidly and significantly decreased after the treatment with ischemia. No remarkable differences were observed in other purine nucleotides, with the exception of inosine monophosphate (IMP) and extracellular hypoxanthine levels, both of which increased significantly during the ischemia. The lactate dehydrogenase activity in culture supernatant of $\mathrm{C}_{2} \mathrm{C}_{12}$ myotubes increased significantly from 2 to $4 \mathrm{hr}$ after the ischemia. On the generation of free radicals, no spectrum was detected in supernatants throughout the observation period, whereas supernatant TBARS concentration increased rapidly and significantly after the ischemia. The relative intensity of $\left[\mathrm{Ca}^{2+}\right] \mathrm{i}$ significantly increased after the ischemia. On the fragmented deoxyribonucleic acid(DNA), no TUNEL positive cells was detected in $\mathrm{C}_{2} \mathrm{C}_{12}$ myotubes after $1 \mathrm{hr}$ of the ischemia, however the positive cell percentage subsequently increased. From these results, it was suggested that the ischemic condition induced changes of membrane permeability and increase of $\left[\mathrm{Ca}^{2+}\right] \mathrm{i}$, both of which lead to cell membrane damage, although a free radical generation was not detected. The ischemic condition also induced the release of substrate hypoxanthine for free radical generation and might initiate the apoptotic pathway in $\mathrm{C}_{2} \mathrm{C}_{12}$ myotubes.

KEY WORDS: apoptotic pathway, $\mathrm{C}_{2} \mathrm{C}_{12}$ myotube, chemical ischemia, free radical generation, purine nucleotide.
\end{abstract}

J. Vet. Med. Sci. 64(6): 483-488, 2002

It is well known that soreness and stiffness develop on the days following severe exercise in horses. This delayed onset muscle soreness is considered to relate with a relative ischemia, in which an imbalance between energetic utilization and generation is induced in the working skeletal muscle $[1,9]$. During the ischemia, major events in the skeletal muscle are reported to develop a decrease of energy charge, a broke down of high-energy phosphates, and an accumulation of those products, such as inosine-5'-monophosphate (IMP), inosine, hypoxanthine, and xanthine $[13,27]$. The decrease of energy charge also induces inadequate ion gradients across the cell membranes, especially calcium ion, which activates certain proteases and converts xanthine dehydrogenase to xanthine oxidase [17].

On the other hand, oxygen free radicals are generated by multiple sources, when $\mathrm{O}_{2}$ may still be present during the ischemia $[5,14,29]$, such as the mitochondrial electron transport chain $[5,7]$ and hypoxanthine-xanthine-uric acid pathway. Oxygen free radicals lead to loss of membrane integrity and cellular functions by the lipid peroxidation of polyunsaturated lipids $[1,19]$, followed by the inactivation

\footnotetext{
* Correspondence to: Ono, K., Department of Clinical Pathobiology, Graduate School of Agricultural and Life Sciences, The University of Tokyo, 1-1-1 Yayoi, Bunkyo-ku, Tokyo 1138657, Japan.
}

of enzymes and increase of intracellular calcium ([Ca $\left.\left.{ }^{2+}\right] \mathrm{i}\right)$ level, both of which in turn could activate various degradative pathways in the working muscle cells [16]. Cytotoxic effects of free radicals were usually enhanced in the reperfusion condition, however some researchers reported that oxidative injury was observed in cardiac tissue during the ischemia without reperfusion $[2,6]$. The activation of apoptotic pathway was considered to be one of the candidates to induce ischemia and/or reperfusion injury [21, 23, 24, 26, 28]. However, there is little information on the exact mechanism of ischemia-induced injury, probably because every step could not be investigated on time in in vivo study.

In this study, to elucidate the mechanisms of ischemiamediated injury in myocytes using mouse-derived $\mathrm{C}_{2} \mathrm{C}_{12}$ myotubes, changes of purine nucleotides, membrane lipid peroxidation, $\left[\mathrm{Ca}^{2+}\right] \mathrm{i}$, generation of free radicals, and deoxyribonucleic acid (DNA) fragmentation were examined under the condition with an inhibition of glycolytic and oxidative metabolism as the ischemic condition.

\section{MATERIALS AND METHODS}

Chemicals: All chemicals used were of analytical grade obtained from Wako Pure Chemical (Osaka, Japan) unless otherwise indicated. All standard compounds for high per- 
formance liquid chromatographic (HPLC) analysis were purchased from Sigma (St. Louis, MO, U.S.A.). The dye of Fluo-3 AM ester and propidium iodide (PI), indicating $\left[\mathrm{Ca}^{2+}\right] \mathrm{i}$ and cell death, respectively, were obtained from Molecular Proves (Eugene, OR, U.S.A.). Dulbecco's modified Eagle medium (D-MEM) was obtained from GIBCO (Gland Island, NY, U.S.A.) and fetal calf serum (FCS) was purchased from JRH (Lenexa, KS, U.S.A.).

Cell culture: Mouse-derived $\mathrm{C}_{2} \mathrm{C}_{12}$ myoblasts [30] (passage number 31 to 45 ) were maintained in D-MEM supplemented with $10 \% \mathrm{FCS}$ at $37^{\circ} \mathrm{C}$ under an atmosphere of $5 \%$ $\mathrm{CO}_{2}$ and $95 \%$ air. $\mathrm{C}_{2} \mathrm{C}_{12}$ myotubes were prepared by culturing confluent myoblast in D-MEM with $2 \%$ FCS. Myotubes between 7- to 9-day old were used for all experiments. The nuclei number was $1.00 \pm 0.04 \times 10^{6}$ (mean $\left.\pm \mathrm{SD}, \mathrm{n}=21\right)$ per a strip and over $95 \%$ of nuclei were in the myotubes. No xanthine oxidase activity was detected in $\mathrm{C}_{2} \mathrm{C}_{12}$ myotubes by the method of Corte and Stirpe [8] with modifications.

Condition of ischemia: $\mathrm{C}_{2} \mathrm{C}_{12}$ myotubes cultured on 25 mm-diameter plastic strips(Nunc, Naperville, Illinois, U.S.A.) were washed 3 times with Hank's balanced saline solution (HBSS; $1.3 \mathrm{mM} \mathrm{CaCl}_{2}, 5.0 \mathrm{mM} \mathrm{KCl}, 0.3 \mathrm{mM}$ $\mathrm{KH}_{2} \mathrm{PO}_{4}, 0.8 \mathrm{mM} \mathrm{MgSO}_{4}, 138 \mathrm{mM} \mathrm{NaCl}, 4.0 \mathrm{mM} \mathrm{NaHCO}$, $0.3 \mathrm{mM} \mathrm{Na}_{2} \mathrm{HPO}_{4}$ and $5.6 \mathrm{mM}$ D-glucose) supplemented with $10 \mathrm{mM} \mathrm{N}$ - [2-hydroxyethyl] piperazine-N'- [2-ethanesulfonic acid] (HEPES, Sigma) at $\mathrm{pH} 7.4$, and pre-incubated for $3 \mathrm{hr}$ in $2.0 \mathrm{ml}$ of the same buffer at $37^{\circ} \mathrm{C}$ under $5 \% \mathrm{CO}_{2} /$ $95 \%$ air. The metabolic inhibition, called as a chemical ischemia, to myotubes was achieved by the incubation in 2.5 $\mathrm{m} l$ of HEPES-HBSS containing $20 \mathrm{mM}$ unutilizable 2deoxyglucose under humid argon gas up to $4 \mathrm{hr}$ at $37^{\circ} \mathrm{C}$.

Evaluation of cell injury: Lactate dehydrogenase (LDH) activities in supernatants were analysed for evaluating the cell membrane injury by a model 736-20 automatic analyser (Hitachi, Tokyo, Japan) with a commercial assay reagents (Wako Pure Chemical, Osaka, Japan).

Analysis of purine nucleotides: Purine metabolites were extracted from myotubes by the method of Lazzarino et al. [15]. Treated plastic strips were inserted into 2- $\mathrm{m} l$ screw capped test tubes. $\mathrm{C}_{2} \mathrm{C}_{12}$ myotubes were deproteinized by the adding $0.5 \mathrm{ml}$ of ice-cold $0.6 \mathrm{mM} \mathrm{HClO}_{4}$ and the vigorous mixing for $1 \mathrm{~min}$. Extracts were neutralized with 0.15 $\mathrm{ml}$ ice-cold $2.0 \mathrm{M} \mathrm{K}_{2} \mathrm{CO}_{3}$ and centrifuged $\left(4^{\circ} \mathrm{C}, 15,000 \times \mathrm{g}\right.$, $2 \mathrm{~min})$. The supernatant was filtrated by a $0.22 \mu \mathrm{m}$ syringe filter (ADVANTEC, Tokyo, Japan) and stored at $-80^{\circ} \mathrm{C}$ until high performance liquid chromatographic (HPLC) assay. The intra-cellular concentrations of adenosine triphosphate (ATP), adenosine diphosphate (ADP), adenosine monophosphate (AMP), guanosine triphosphate (GTP), guanosine diphosphate (GDP), and inosine monophosphate (IMP) were measured with an HPLC system (JASCO, Tokyo, Japan). The system consisted of two model PU-980 pump, an AS-950 sampler, a CO-965 column oven, an UV970 detector, and an LCSS-905 integrator. The chromatographic analysis was performed at a flow rate of $1.2 \mathrm{ml} / \mathrm{min}$ on a $250 \times 4.6 \mathrm{~mm}$ Pegasil ODS column (Senshu, Tokyo, Japan) maintained at $40^{\circ} \mathrm{C}$. The mobile phase consisted of
$10 \mathrm{mM}$ tetrabutylammonium hydroxide, $25 \mathrm{mM} \mathrm{KH}_{2} \mathrm{PO}_{4}$, and $1.0 \%$ methanol at pH 6.5 (solvent $\mathrm{A}$ ), and $5 \mathrm{mM}$ tetrabutylammonium hydroxide, $100 \mathrm{mM} \mathrm{KH}_{2} \mathrm{PO}_{4}$, and $30 \%$ methanol at $\mathrm{pH} 4.5$ (solvent $\mathrm{B}$ ). A linear gradient from 0 to $100 \%$ of buffer B was formed between 10 and $50 \mathrm{~min}$. A $50 \mu \mathrm{l}$ of sample aliquot was injected and the eluant was monitored at $266 \mathrm{~nm}$ and 0.64 AUFS. Total procedure time was $50 \mathrm{~min}$. The initial conditions were restored after over $20 \mathrm{~min}$ of washing with buffer A. Calibration curves for the quantitative measurements of the biological samples were prepared by analysing standard solutions with different known concentrations.

Analysis of free radicals by spin-trapping method: For the spin-trapping method, an electron spin resonance (ESR) signals were measured in $\mathrm{C}_{2} \mathrm{C}_{12}$ myotubes preincubated in the presence of $40 \mathrm{mM} \mathrm{5,5-dimethyl-1-pyrroline-N-oxide}$ (DMPO). Then, the cells were cultured under the ischemic condition for 1, 2 and $3 \mathrm{hr}$, as described above. The culture supernatant was withdrawn into a flat quartz cell $(60 \times 10 \times$ $0.3 \mathrm{~mm}$ inner size) and place in the stage of a JEOL Model JES-FA 100 ESR spectrometer (JEOL, Tokyo, Japan). All ESR spectra were recorded at room temperature and the spectrometer settings were: magnetic field $336.5 \pm 5 \mathrm{mT}$, sweep time $2.0 \mathrm{~min}$, modulation frequency $100 \mathrm{kHz}$, modulation amplitude $0.1 \mathrm{mT}$, receiver gain $2.5 \times 10^{3}$, time constant $0.1 \mathrm{~s}$, microwave frequency $9.415 \mathrm{GHz}$, and microwave power $14 \mathrm{~mW}$.

Assay for supernatant thiobarbituric acid reactive substances: Thiobarbituric acid reactive substances (TBARS) released into the supernatant were measured by a thiobarbituric acid (TBA) method as described by Schmedes and Hølmer [25]. The TBA reagent was prepared by dissolving $1 \%(\mathrm{w} / \mathrm{v})$ TBA (Merck, Darmstadt, B.R.D.) in 5\% trichloroacetic acid (Wako Pure Chemical, Osaka, Japan) solution. The $1.0 \mathrm{~m} l$ of the extracts (the Bligh-Dyer aqueous phase) was mixed with $1.0 \mathrm{ml}$ of the TBA reagent in a screwcapped test tube. The tightly capped test tube was heated in a water bath at $95^{\circ} \mathrm{C}$ for $30 \mathrm{~min}$, cooled in tap water, and centrifuged at $1,500 \times \mathrm{g}$ to assure a clear solution. The fluorescent intensity was measured by a model 650-10S fluorescence spectrophotometer (Hitachi, Tokyo, Japan) at Ex $515 \mathrm{~nm}$ and $\mathrm{Em} 553 \mathrm{~nm}$.

Analysis for intracellular calcium ([Ca2+]i) level: $\mathrm{C}_{2} \mathrm{C}_{12}$ myotubes were incubated on a glass cover slip with $10 \mu \mathrm{M}$ of fluo-3/AM in HEPES-HBSS at $37^{\circ} \mathrm{C}$ for $30 \mathrm{~min}$ during pre-incubation time. After washing 3 times with HEPESHBSS, the cells cultured were exposed to the ischemic condition on the cover slip and kept at $37^{\circ} \mathrm{C}$ for 1,2 and $3 \mathrm{hr}$. As an indicator of the cell death, $10 \mu \mathrm{M}$ of propidium iodide (PI), which entered cells due to the loss of membrane integrity and stained the nucleus, was used. The cells were imaged using the InSIGTH PLUSTM laser scanning confocal microscope system (Meridiam, Okemos, MI, U.S.A.). The two dyes were simultaneously excited at $488 \mathrm{~nm}$ argon laser line, and emissioned at 530/30 nm for fluo-3 and at $605 / \mathrm{LP}$ nm for PI, respectively.

Fluorescence intensities were recorded every $60 \mathrm{sec}$ for 
30 min and analysed with InSIGHT-IQ analysis software. The changes of $\left[\mathrm{Ca}^{2+}\right] \mathrm{i}$ were represented in each single cell.

Detection of fragmented DNA: DNA fragmentation was examined on $\mathrm{C}_{2} \mathrm{C}_{12}$ myotubes cultured on the cover slip by the modified TUNEL method proposed by Gavrieli et al. [12], using a commercial apoptosis detection kit (Apop Tag, Oncor, Gaithersburg, MD). The ratio of TUNEL-positive cells to all the cells was calculated on the 3 cells cultured on a cover slip slides under light microscope, and then the mean $\pm \mathrm{SD}$ of 3 slides was expressed as a percentage at 1,2 and $3 \mathrm{hr}$ after the ischemia.

Statistical analysis: All statistical analyses were performed using Student's $t$-tests for unpaired data.

\section{RESULTS}

Purine nucleotides: ATP and GTP concentrations in $\mathrm{C}_{2} \mathrm{C}_{12}$ myotubes rapidly and significantly decreased $(p<0.001$ and $\mathrm{p}<0.05$, respectively) at $1 \mathrm{hr}$ after the treatment with ischemia, maintaining low levels during the following $3 \mathrm{hr}$. No remarkable differences were observed in other purine nucleotides, with the exception of IMP and extracellular hypoxanthine levels, both of which increased significantly $(\mathrm{p}<0.05)$ during the ischemia (Fig. 1).

Cell viability: The supernatant $\mathrm{LDH}$ level of $\mathrm{C}_{2} \mathrm{C}_{12}$ myotubes increased significantly $(p<0.05)$ from 2 to $4 \mathrm{hr}$ after the treatment with ischemia (Fig. 2).

Generation of free radicals: Figure 3 shows typical ESR spectra of culture supernatants during the ischemia by the spin-trapping method. No spectrum was detected in supernatants throughout the observation period.

Lipid peroxidation: Lipid peroxidation was determined as the changes of the supernatant TBARS levels. Supernatant TBARS concentration increased rapidly and significantly $(\mathrm{p}<0.001)$ after $1 \mathrm{hr}$ of the ischemia (Fig. 4).

Intracellular calcium $([\mathrm{Ca} 2+] i)$ : During the ischemia, $\mathrm{C}_{2} \mathrm{C}_{12}$ myotubes showed an increase of $\left[\mathrm{Ca}^{2+}\right] \mathrm{i}$ as indicated by fluo-3 fluorescence, whereas the cell death indicated by PI was not detected. After $1 \mathrm{hr}$ of the ischemia, the relative intensity of $\left[\mathrm{Ca}^{2+}\right] \mathrm{i}$ increased by $47 \%$, being more increase of it after 2 and $3 \mathrm{hr}$ (78\% and 71\%, respectively) of the ischemia (Fig. 5).

Fragmented DNA: Typical patterns of TUNEL positive cells during ischemia are shown in Fig. 6. After $1 \mathrm{hr}$ of the ischemia, no TUNEL positive cells was detected in $\mathrm{C}_{2} \mathrm{C}_{12}$ myotubes, however the positive cell percentage increased to $1.33 \%$ at $2 \mathrm{hr}$ of the ischemia and subsequently increased $(4.33 \%)$ after $3 \mathrm{hr}$.

\section{DISCUSSION}

In the skeletal muscle during the ischemia, energetic impairments, free radical-mediated lipid peroxidation, $\left[\mathrm{Ca}^{2+}\right] \mathrm{i}$ increase, and membrane injury were common events $[1,19]$, however, the relationship among them has not been completely elucidated. In the present study, we attempted to prepare the ischemic condition for in vitro $\mathrm{C}_{2} \mathrm{C}_{12}$ myotubes a)

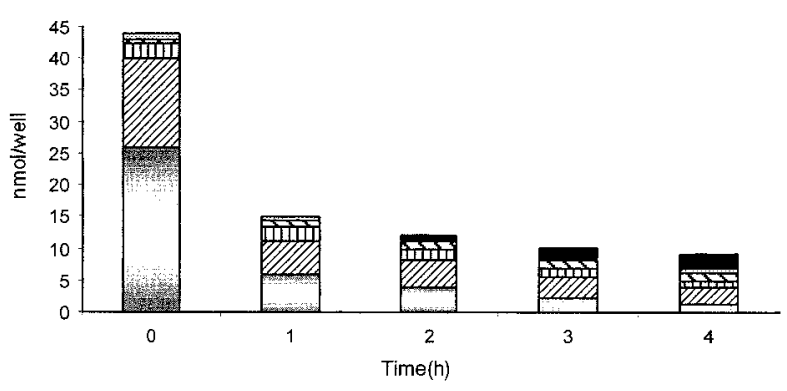

b)

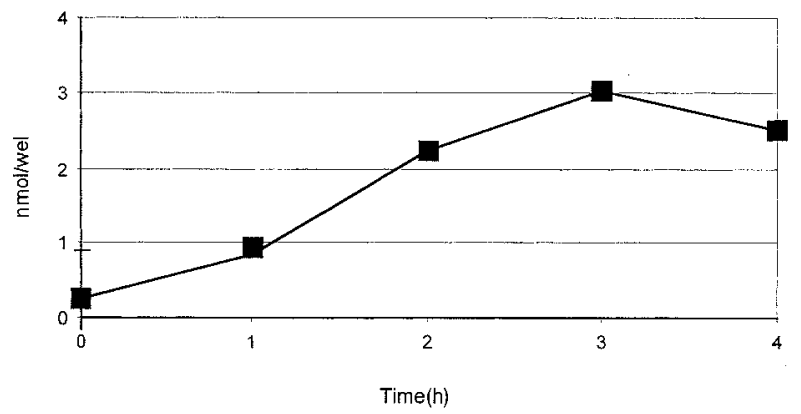

Fig. 1. Changes of intracellular purine nucleotides (a) (ATP GTP 四, ADP 血, GDP $\square$, AMP $\square$, IMP $\square$ ) and supernatant hypoxanthine levels (b) in $\mathrm{C}_{2} \mathrm{C}_{12}$ myotubes during the ischemia.

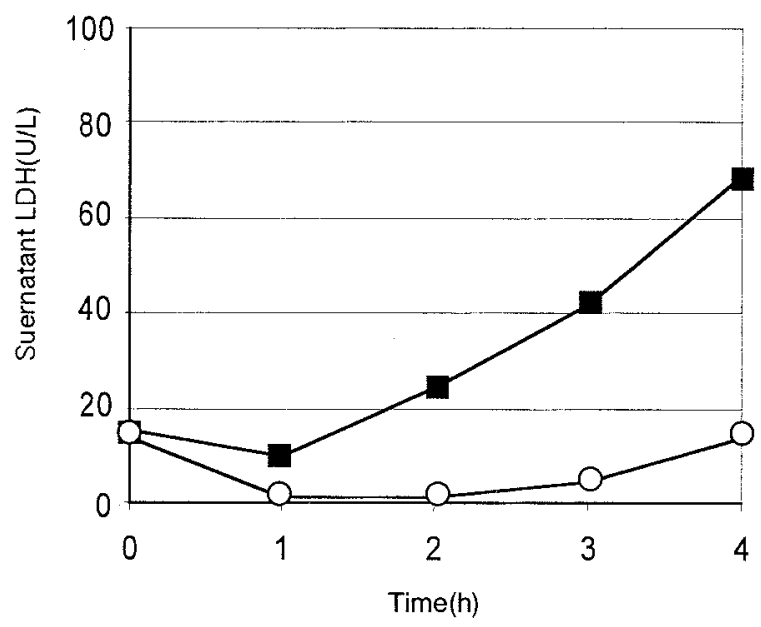

Fig. 2. Changes of LDH release (control: $-\mathrm{O}$ - ischemia: from $\mathrm{C}_{2} \mathrm{C}_{12}$ myotubes during the ischemia.

by the inhibition of glycolytic- and oxidative-metabolism. Results of this experiment clearly showed that high-energy phosphates, especially ATP and GTP, rapidly and significantly decreased by the first hour of the ischemia, and the reduction of high-energy phosphates was maintained for subsequent $3 \mathrm{hr}$. These data supported previous in vivo and in vitro studies, reporting that the major event was the ATP 
a) control

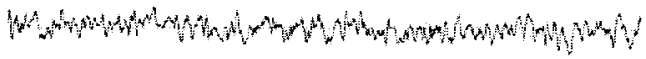

\section{b) ischemia}

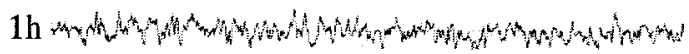

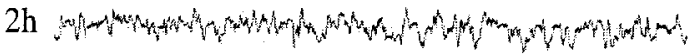

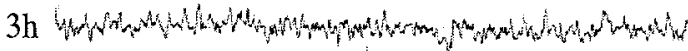

Fig. 3. Typical ESR spectra in supernatants of $\mathrm{C}_{2} \mathrm{C}_{12}$ myotubes during the ischemia. Each spectrum was recorded by single scan with the constant analytical condition as described in Materials and Methods.

loss during the ischemia $[13,27]$. The end product of ATP degradation is hypoxanthine, which increased in the extracellular space during the ischemia in this study, although the level of hypoxanthine produced was unexpectedly low and was not equivalent to the decrease of intracellular highenergy nucleotides. Uric acid and allantoin, both of which were the final products of purine degradation in mammalian

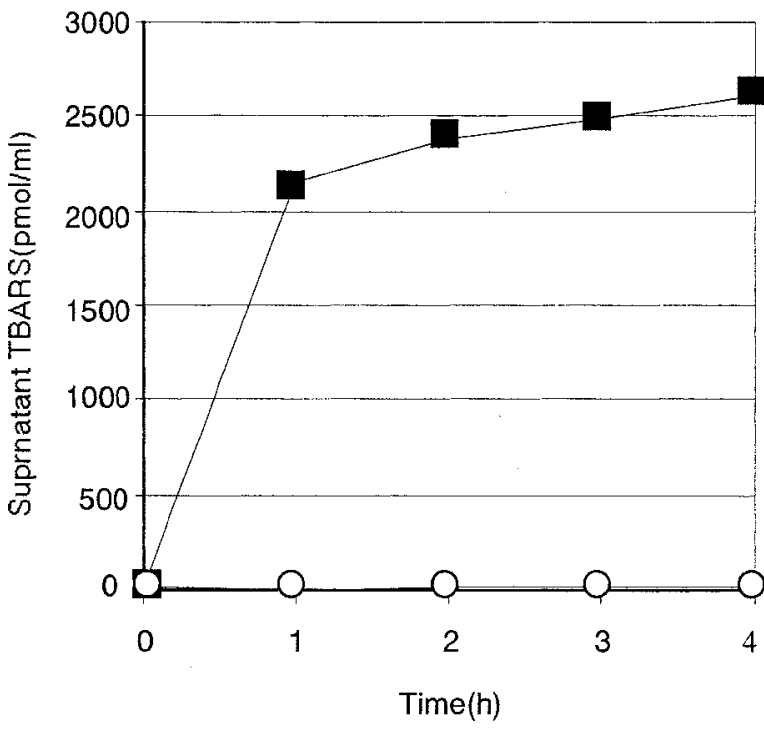

Fig. 4. Changes of supernatant TBARS release (control: $-\mathrm{O}$ ischemia: - - ) from $\mathrm{C}_{2} \mathrm{C}_{12}$ myotubes during the ischemia.

cells during the ischemia, were not detected throughout the experimental period in this culture system, since $\mathrm{C}_{2} \mathrm{C}_{12}$ myotubes had no xanthine oxidase activity, which converted hypoxanthine to xanthine and uric acid.

During the ischemia, the supernatant LDH values increased significantly. This data was well agreed with the previous in vivo and in vitro studies, in which increase of $\mathrm{LDH}$ value during the ischemia was due to the changes of membrane permeability and/or cell death by lipid peroxida- a)

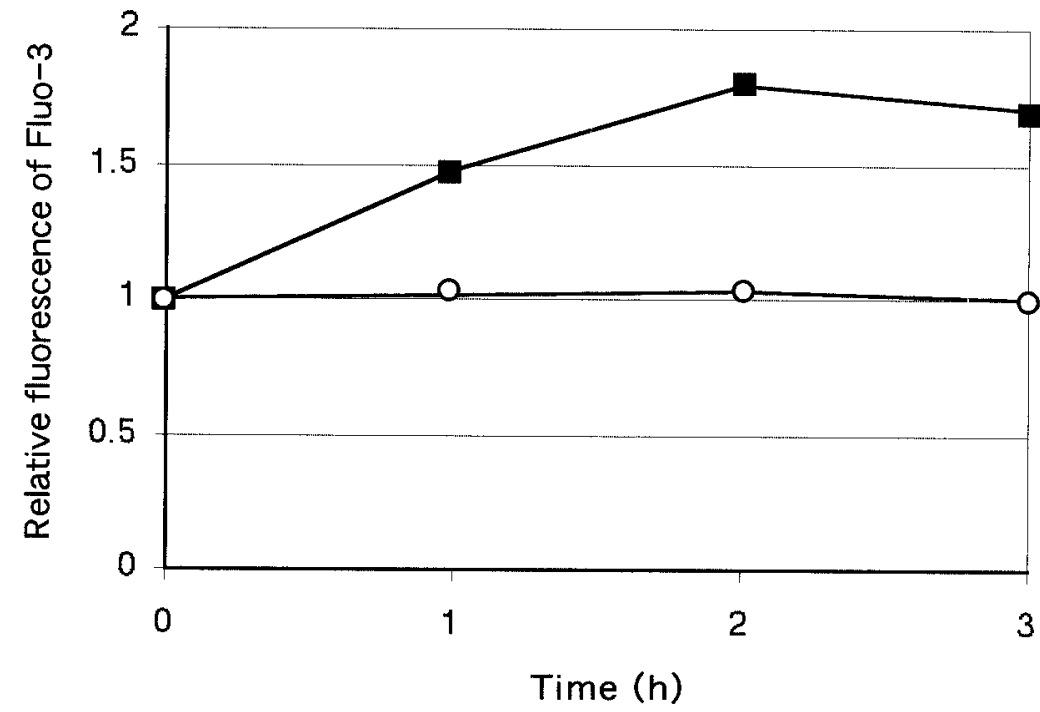

b)

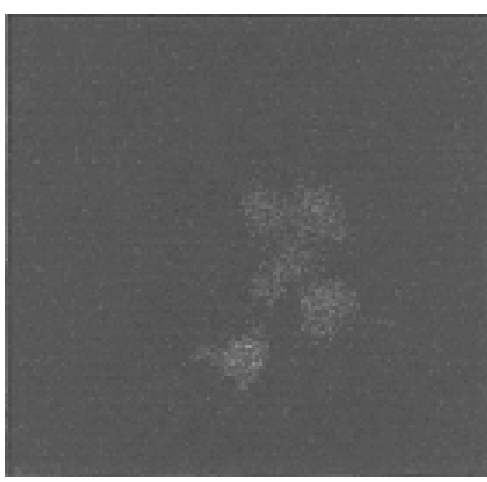

Fig. 5. Changes of the intracellular calcium level (control: $-\bigcirc-$, ischemia: fluorescence after $3 \mathrm{hr}$ of the ischemia (b). Data were represented as a relative fluorescence of Fluo-3. 
a)

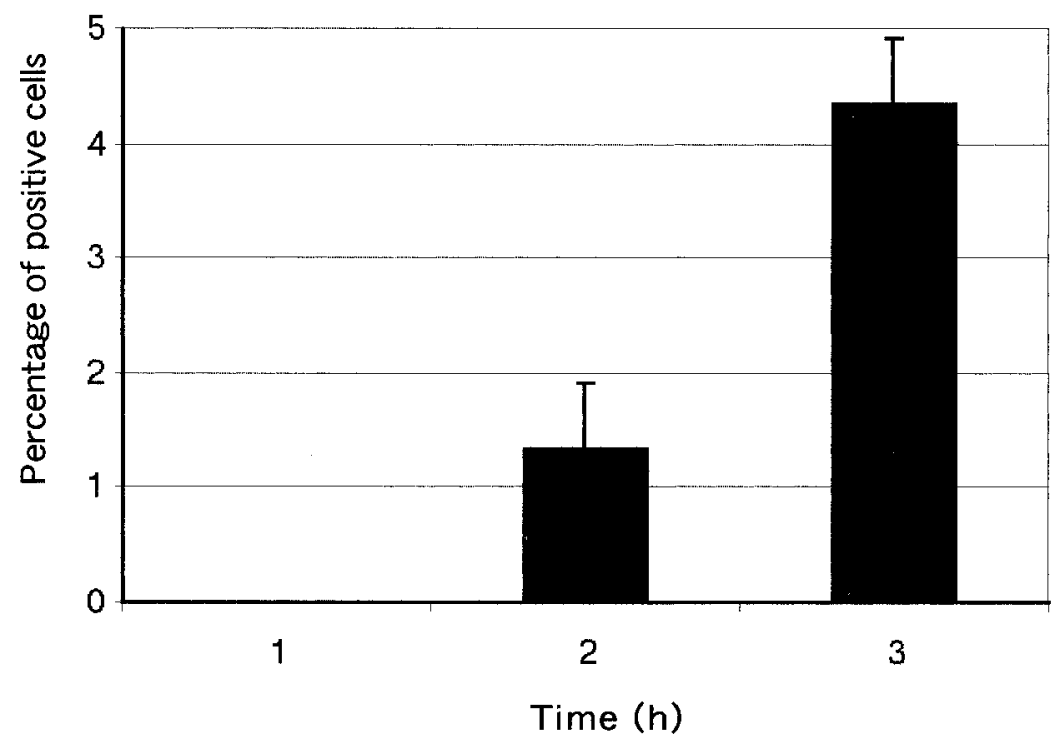

b)

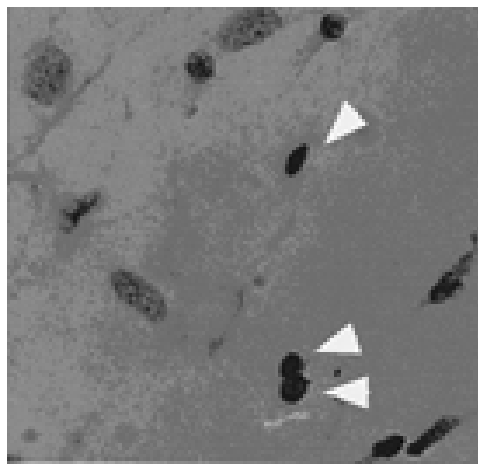

Fig. 6. Changes of TUNEL positive cells during the ischemia (a) and typical patterns of TUNEL positive cells after 3 hr of the ischemia (b). Bars indicate standard deviation of the mean. Arrowhead shows a TUNEL positive nuclei $(\times 20)$.

tion [31]. The cell membrane is well known as the major target of free radicals, because it contains large amount of polyunsaturated fatty acids. In this study, it was notable that TBARS concentration increased in the extracellular space during the ischemia. This finding suggested that the lipid peroxidation was induced during the ischemia, however no ESR spectra was detected by the spin trapping method. Therefore, TBARS level increased in supernatant was not related to the free radical-induced lipid peroxidation, but to the release of peroxidized lipid from the cell membrane, probably by the acidosis $[3,4,20]$ and/or activation of phospholipase pathway during the ischemia [11].

In this study, $\left[\mathrm{Ca}^{2+}\right] \mathrm{i}$ significantly increased in $\mathrm{C}_{2} \mathrm{C}_{12}$ myotubes during the ischemia. The major cause of this was considered to be the changes of permeability of the sarcolemma [22], resulted in abnormal distribution of $\left[\mathrm{Ca}^{2+}\right] \mathrm{i}$ in the cells $[11,18]$. The reduction of ATP concentration also induced $\left[\mathrm{Ca}^{2+}\right] \mathrm{i}$ increase by the inactivation of the $\mathrm{Ca}^{2+}$ ATPase located in the vicinity of the sarcolemma [10]. The increased $\left[\mathrm{Ca}^{2+}\right] \mathrm{i}$ in $\mathrm{C}_{2} \mathrm{C}_{12}$ myotubes during the ischemia might activate phospholipase, by which release of TBARS was developed. However, it was not enough to produce the cell death, indicating by the no increase of PI fluorescence in $\mathrm{C}_{2} \mathrm{C}_{12}$ myotubes during the ischemia.

To examine the DNA fragmentation, the TUNEL method was performed on $\mathrm{C}_{2} \mathrm{C}_{12}$ myotubes. The number of positive cells increased during the ischemia, reaching at $4.33 \%$ after $3 \mathrm{hr}$ of the ischemia. Some chromosomal DNA damage was induced in $\mathrm{C}_{2} \mathrm{C}_{12}$ myotubes during the ischemia, although no DNA fragmentation was detected by the gel electrophoresis (data not shown).

In conclusion, it was suggested that the ischemic condition induced changes of membrane permeability and itracellular calcium ion increase, both of which lead to cell membrane damage, although a free radical generation was not detected. The ischemic condition also induced the release of substrate hypoxanthine for free radical generation and initiated the apoptotic pathway in $\mathrm{C}_{2} \mathrm{C}_{12}$ myotubes.

\section{REFERENCES}

1. Arabadjis, P.G., Tullson, P.C. and Terjung, R.L. 1993. Purine nucleoside formation in rat skeletal muscle fiber types. Am. $J$. Physiol. 264: C1246-C1251.

2. Arroyo, C.M., Kramer, J.H., Leiboff, R.H., Mergner, G.W., Dickens, B.F. and Weglicki, W.B. 1987. Spin trapping of oxygen and carbon-centered free radicals in ischemic canine myocardium. Free Rad. Biol. Med. 3: 313-316.

3. Avkiran, M. 1999. Rational basis for use of sodium-hydrogen exchange inhibitors in myocardial ischemia. Am. J. Cardiol. 83: 10G-18G.

4. Back, T., Hoehn, M., Mies, G., Busch, E., Schmitz, B., Kohno, K. and Hossmann, K.A. 2000. Penumbral tissue alkalosis in focal cerebral ischemia: relationship to energy metabolism, blood flow, and steady potential. Ann. Neurol. 47: 485-492.

5. Becker, L. B., Vanden Hoek, T.L., Shao, Z., Li, C. and Schumacker, P.T. 1999. Generation of superoxide in cardiomyocytes during ischemia before reperfusion. Am. J. Physiol. 277: H2240-H2246.

6. Bolli, R., Patel, B.S., Jeroudi, M.O., Lai, E.K. and McCay, P.B. 1988. Demonstration of free radical generation in "stunned" myocardium of intact dog with N-tert-butyl nitrone. J. Clin. 
Invest. 82: 476-485.

7. Boveris, A. 1977. Mitochondrial production of superoxide radical and hydrogen peroxide. Adv. Exp. Med. Biol. 78: 67-82.

8. Corte, E.D. and Stirpe, F. 1968. Regulation of xanthine oxidase in rat liver: modifications of the enzyme activity of rat liver supernatant on storage at 20 degrees. Biochem. J. 108: 349351.

9. Davies, K.J.A., Quintanilha, A.T., Brooks, G.A. and Packer, L. 1982. Free radicals and tissue damage produced by exercise. Biochem. Biophys. Res. Commun. 107: 1198-1205.

10. Duchen, M.R., Valdeomillos, M., Oneill, S.C. and Eisner, D.A. 1990. Effects of metabolic blockade on the regulation of intracellular calcium in dissociated mouse sensory neurones. J. Physiol. (Lond.) 424: 411-426.

11. Farooqui, A.A., Yang, H.C. and Horrocks, L. 1997. Involvement of phospholipase A2 in neurodegeneration. Neurochem. Int. 30: 517-522.

12. Gavrieli, Y., Sherman Y. and Ben-Sasson, S.A. 1992. Identification of programmed cell death in situ via specific labeling of nuclear DNA fragmentation. J. Cell Biol. 119: 493-501.

13. Idstrom, J.P., Soussi, B., Elander, A. and Bylund-Fellennius, A.C. 1990. Purine metabolism after in vivo ischemia and reperfusion in rat skeletal muscle. Am. J. Physiol. 258: H1668H1673.

14. Kobayashi, A., Watanabe, H., Ozawa, K., Hayashi, H. and Yamazaki, N. 1989. Oxygen derived free radicals related injury in heart during ischemia and reperfusion. Jpn. Circ. J. 53: 1122

15. Lazzarino, G., Nuutinen, M., Tabazzi, B., Di Pierro, D. and Giardina, B. A. 1989. Method for preparing freeze-clamped tissue samples for metabolite analyses. Anal. Biochem. 181: 239241.

16. Malis, C.D. and Boventre, J.V. 1988. Susceptibility of mitochondrial membranes to calcium and reactive oxygen species: implications for ischemic and toxic tissue damage. Prog. Clin. Biol. Res. 282: 235-259.

17. McCord, J.M. 1985. Oxygen-derived free radicals in postischemic tissue injury. New Engl. J. Med. 312: 159-163.

18. Oe, H., Kuzuya, T., Hoshida, S., Nishida, M., Hori, M., Kamada, T. and Tada, M. 1994. Calcium overload and cardiac myocite cell damage induced by arachidonate lipoxygeneration. Am. J. Physiol. 267: H1396-H1402.

19. Parinandi, N.L., Zwizinski, C.W. and Schmid, H.H.O. 1991. Free radical-induced alteration of myocardial membrane proteins. Arch. Biochiem. Biophys. 289: 118-123.
20. Park, C.O., Xiao, X.H. and Allen, D.G. 1999. Changes in intracellular $\mathrm{Na}^{+}$and $\mathrm{pH}$ in rat heart during ischemia: role of $\mathrm{Na}^{+} / \mathrm{H}^{+}$ exchanger. Am. J. Physiol. 276: H1581-H1590.

21. Podhorka-Okolov, M., Sandri, M. and Bruson, A. 1995. Apoptotic myonuclei appear in adult skeletal muscle of normal and mdx mice after a mild exercise. Basic Appl. Myol. 5: 87-90.

22. Quintanilha, A.T., Packer, L., Davies, J.M., Racanelli, T.L. and Davies, K.J.A. 1982. Membrane Effects of vitamin E deficiency: bioenergetic and surface charge density studies of skeletal muscle and liver mitochondria. Ann. New York Acad. Sci. 393: $32-47$.

23. Sandri, M., Carraro, U., Podhorka-Okolov, M., Rizzi, C., Arslan, P., Monti, D. and Franceschi, C. 1995. Apoptosis, DNA damage and ubiquitin expression in normal and $\mathrm{mdx}$ muscle fibers after exercise. FEBS Lett. 373: 291-295.

24. Sandri, M., Podhorka-Okolov, M., Geromel, V., Rizzi, C., Arslan, P., Franceschi, C. and Carraro, U. 1997. Exercise induces myonuclear ubiquitination and apoptosis in dystrophin deficient muscle of mice. J. Neuropathol. Exp. Neurol. 56: 4557.

25. Schmedes, A. and Hølmer, G. 1989. A new thiobarbituric acid (TBA) method for determining free malondialdehyde (MDA) and hydroperoxides selectively as a measure of lipid peroxidation. J. Am. Oil Chem. Soc. 66: 813-817.

26. Smith, J. 1996. Muscle growth factors, ubiquitin, and apoptosis in dystrophic muscle: apoptosis decline with age in the $\mathrm{mdx}$ mouse. Basic Appl. Myol. 6: 279-284.

27. Soussi, B., Idstrom, J.P., Schersten, T. and Bylund-Fellenius, A.C. 1990. Dynamics of skeletal muscle energetics during ischemia and reperfusion assessed by in vivo ${ }^{31} \mathrm{P}$ NMR. NMR Biomed. 3: 71-77.

28. Tidball, J.G., Albrecht, D.E., Lokensgard, B.E. and Spencer, M.J. 1995. Apoptosis precedes necrosis of dystrophin-deficient muscle. J. Cell Sci. 108: 2197-2204.

29. Vanden Hoek, T.L., Li, C., Shao, Z., Schumacker, P.T. and Becker, L.B. 1997. Significant levels of oxidants are generated by isolated cardiomyocytes during ischemia prior to reperfusion. J. Mol. Cell Cardiol. 29: 2571-2583.

30. Yaffe, D. and Saxel, O. 1977. Serial passaging and differentiation of myogenic cells isolated from dystrophic mouse muscle. Nature (Lond.) 270: 725-727.

31. Zhu, W. and Fung, P.C. 2000. The roles played by crucial free radicals like lipid free radicals, notric oxide, and enzymes NOS and NADPH in $\mathrm{CCl}$ (4)-induced acute liver injury of mice. Free Radic. Biol. Med. 29: 870-880. 